\title{
Trajetória da revisão judicial no desenho constitucional brasileiro: tutela, autonomia e judicialização'
}

ERNAN GARUALO"

\section{Resumo}

As instituições judiciárias ficaram por muito tempo na sombra dos fenômenos e da teoria política estudadas na América Latina. Neste texto trago algumas reflexões em torno de uma dessas instituições, a revisão judicial. A ideia central é demonstrar a trajetória deste instrumento jurídico que se tornou uma peça chave no entendimento da judicialização da política no Brasil. Neste sentido, tentaremos mapear os fatores que potencializam a judicialização da política tomando como pano de fundo a evolução das instituições judiciais brasileiras no período republicano, especificamente as instituições responsáveis pela revisão judicial.

Palavras-chave: Revisão judicial. Autonomia. Judicialização.

\footnotetext{
* Doutor em Ciência Política pela USP, Professor e Pesquisador do Programa de Pós-Graduação em Ciência Política da UFPE.

1 Este artigo é um capítulo revisto da minha tese de doutorado. Agradeço aos membros da banca pelos comentários.
} 


\section{Introdução}

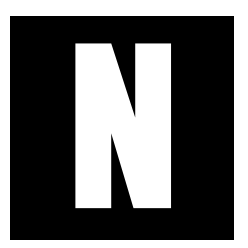

este artigo tentaremos mapear os fatores que potencializam a judicialização da política ${ }^{2}$ tomando como pano de fundo a evolução das instituições judiciais brasileiras no período republicano, especificamente as instituições responsáveis pela revisão judicial. Para tanto, reconstruiremos a trajetória de implantação e desenvolvimento do controle de constitucionalidade e as alterações no desenho institucional do Supremo Tribunal Federal.

Argumentamos que o desenho constitucional tornou-se o grande protagonista das alterações ocorridas no processo decisório judicial, principalmente a opção pela revisão abstrata. A expansão do poder judicial deve-se, em boa medida, às alterações institucionais que fortaleceram a autonomia do Judiciário e aumentaram a possibilidade de participação da sociedade no litígio constitucional abstrato.

Por outro lado, este novo desenho institucional redefiniu as formas de decidir na política nacional. Atualmente, parte significativa do processo decisório sofre de algum constrangimento judicial. Este novo cenário requer uma maior atenção dos cientistas políticos sobre como os tribunais decidem.

\section{A Constituição de 1891 e a República}

A promulgação da primeira Constituição republicana foi um marco na história política brasileira. A Carta de 1891 estabeleceu os pilares da ordem política - separação dos poderes, presidencialismo, federalismo, duplo grau de jurisdição, controle de constitucionalidade, tribunal consti-

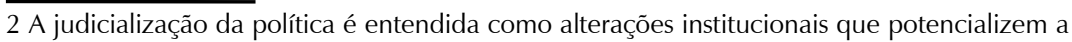
participação do Judiciário no processo decisório. 
tucional etc. - vigentes até hoje. A construção desse consenso político foi marcada por intensos debates e confrontação de ideias. Para os fins deste trabalho cabe aqui os destaques ao desenho institucional dado ao Supremo Tribunal Federal e à importação do modelo de controle de constitucionalidade norte-americano e junto com ele a possibilidade jurídica do exercício de controle dos poderes representativos por parte do Judiciário.

A mais alta Corte do país foi fundada por obra do decreto executivo de no 848 de 11/10/1890, redigido pelo então Ministro da Justiça, Campos Sales. O primeiro sistema de controle de constitucionalidade brasileiro, controle difuso, foi "importado" dos Estados Unidos e aplicado tal e qual no Brasil.

Como sabemos, o Poder Judiciário no Império era quase um apêndice do Executivo. "O Poder Judicial era distinto apenas funcionalmente do poder imperial. Essa forma de divisão manifestava-se na competência do poder judicial, ao qual era vedado o julgamento de qualquer questão que envolvesse o poder político" (KOERNER, 1998, p. 34).

Na prática, cabia ao Judiciário a resolução dos conflitos entre particulares ou, em uma linguagem jurídica, a administração do princípio pacta sunt servanda. Em suma, era vedado ao Poder Judiciário o conhecimento de questões de interesse geral como forma de interferir na política. Como bem lembra José Eduardo Faria, o direito era concebido como "um saber técnico e racional destinado à conciliação de interesses individuais e à preservação de interesses gerais, por meio de uma razão instrumental que, valorizando o universal, o abstrato e o formal em detrimento do particular, do concreto e do material, julga-se em condições de produzir seguranças e certezas" (FARIA, 1989, p. 10).

Embora a atuação do Poder Judiciário no Império estivesse, em grande monta, restrita aos conflitos entre particulares, os juízes, com frequência eram recrutados para compor o corpo político e administrativo do Estado imperial. "Havia forte presença de magistrados em cargos 
eletivos e de nomeação dos outros poderes. No período 1822- 1853, $41,71 \%$ dos ministros e $44,41 \%$ dos Senadores eram magistrados, com uma participação semelhante no Conselho de Estado, no mesmo período" (KOERNER, apud CARVALHO, 1998, p. 46). O magistrado imperial ocupava uma dupla função de apaziguador dos conflitos sociais cotidianos e administrador público. Essa dupla função está fortemente vinculada ao protagonismo político e administrativo exercido pelo bacharel de direito na sociedade portuguesa, principalmente em seu período colonial (SCHWARTZ, 1979, p. 03-73). O protagonismo em termos político e administrativo fez-se presente não apenas na magistratura, mas militares e sarcedotes também ocuparam um lugar de destaque na construção do Estado brasileiro (CARVALHO, 1998).

De mediador político no Império para magistrado moderno na República. Como atenta Arantes (1994), as palavras do Ministro da Justiça, Campos Sales, no preâmbulo do decreto 848, de 11/10/1890, informam bem quais as diferenças entre o magistrado imperial e o magistrado republicano:

A magistratura que agora se instala no país, graças ao regime republicano, não é instrumento cego ou mero intérprete dos atos do poder legislativo. Antes de aplicar a lei, cabe-lhe o direito de exame, podendo dar-Ihe ou recusar-Ihe sanção se ela parecer conforme ou contrária à lei orgânica (ARANTES, apud BALEEIRO, 1994, p. 52-53).

Do ponto de vista teórico, é interessante notar que o juiz foi deslocado de uma posição informal - pois não havia nada que atestasse seu papel do ponto de vista jurídico - de mediador entre as políticas locais e o centro do poder imperial, para uma posição formalizada e totalmente estruturada constitucionalmente - separação dos poderes, federalismo e controle de constitucionalidade - de árbitro dos conflitos públicos ${ }^{3}$.

3 O juiz passa formalmente a poder julgar questões do interesse público. Teoricamente sua condição de mediador é revestida de prerrogativas constitucionais que supostamente quebrariam os grilhões de dependência existentes na forma imperial. 
A posição anterior, ou seja, a posição do magistrado no Império, caracterizava-se pela absorção do magistrado pelo sistema político. Caso o magistrado desempenhasse um papel relevante para a Coroa teria boas chances de ocupar um bom cargo na administração pública imperial e até de ingressar na carreira política ${ }^{4}$. O papel de mediador informal transformou-se na escola política da magistratura imperial. Ao formalizar a atuação do magistrado como árbitro político, com o estabelecimento do controle de constitucionalidade difuso, a Constituição republicana de 1891 diminui, sensivelmente, o espectro de atuação política dos juízes. No entanto, a formalização produz uma maior autonomia do Judiciário em relação aos poderes representativos. Em outras palavras, ocorreu um enquadramento do juiz na doutrina clássica da separação dos poderes, que, em tese, significa, por um lado, a diminuição de sua importância no cenário político nacional à medida que os juízes deixaram de ser recrutados para compor a elite política e burocrática do país, por outro lado, a autonomia abre caminho para uma participação política mais discreta e teoricamente imparcial. Em suma, apesar de ser afastado do sistema político tradicional, a magistratura brasileira é convidada a participar desse sistema por outra via, mais afeita à doutrina liberal da época e revestida de garantias funcionais.

\section{A Constituição de 1934 e os sinais do Controle Concentrado}

Entre a Constituição de 1891 e a de 1934 a história política brasileira foi muito conturbada. Nesse campo, a Política dos Governadores e a Revolução de 1930 marcaram o período. A primeira caracterizou-se pela troca de favores políticos entre o poder local ou regional e o poder cen-

4 Essa era uma prática corrente também em Portugal. A criação de uma burocracia administrativa, no sentido estrito da palavra, só foi possível com as reformas pombalinas (SCHWARTZ, 1979, p. 03-18). 
tral. São Paulo e Minas Gerais dominaram esse cenário de trocas através do controle da Presidência da República.

A segunda, por meio do movimento revolucionário de 30 e com a posse do Presidente Getúlio Vargas, intervém de forma brusca nos Estados federados, liquida a política dos governadores, manda desarmar os coronéis desestruturando toda a base de poder da assim chamada "República Velha".

No que se refere à reengenharia constitucional, antes mesmo da Constituição de 1934 entrar em vigor alguns decretos presidenciais já davam o tom das mudanças. Dentre os decretos podemos citar: em 08/11/31, Vargas baixou de quinze para onze o número de ministros do Supremo Tribunal Federal (STF); em 23/11/31, aposentou de forma sumária seis ministros do STF, alegando razões de ordem pública ${ }^{5}$. Dentre os ministros aposentados alguns se destacavam por serem opositores do regime revolucionário getulista; em 03/02/32, instituiu o Código Eleitoral que permitia ao Judiciário julgar a validade das eleições e proclamar os eleitos ${ }^{6}$.

Segundo José Afonso da Silva (2002), a Constituição de 1934 não trouxe, no geral, conteúdo novo, mantendo os princípios formais e fundamentais da anterior - a república, o federalismo, o presidencialismo, a separação dos poderes etc. Mas, nem tudo foi igual: a nova Constituição

aumentou os poderes do Executivo. Rompeu com o bicameralismo rígido, atribuindo o exercício do Poder Legislativo apenas para a Câmara dos Deputados, transformando o Senado Federal em órgão de colaboração desta (...) Ao lado da clássica declaração de direito e garantias individuais, inscreveu um título sobre a ordem econômica e social e outro sobre a família, a educação e a cultura, com normas quase

5 É interessante destacar que o surgimento e as alterações na estrutura do Supremo Tribunal Federal brasileiro continuaram sendo feitas por decretos do Executivo.

6 Antes, o julgamento da validade do pleito e a proclamação dos eleitos eram realizados pelo próprio poder político, o que gerou toda sorte de injustiças e perseguições políticas. 
todas programáticas, sob a influência da Constituição alemã de Weimar (SILVA, 2002, p. 82).

No que tange ao controle de constitucionalidade, especificamente, a Constituição de 1934 introduziu profundas e significativas alterações. Apesar de sua brevidade, vale a pena ressaltar estas alterações devido à sua recorrência nas Constituições posteriores:

1) "O constituinte determinou que a declaração de inconstitucionalidade somente poderia ser realizada pela maioria da totalidade de membros dos tribunais. Evitava-se a insegurança jurídica decorrente das contínuas flutuações de entendimento nos tribunais" (MARTINS; MENDES, 2001, p. 23);

2) A mesma Constituição atribuiu ao Senado a competência de "suspender a execução, no todo ou em parte, de qualquer lei ou ato, deliberação ou regulamento, quando hajam sido declarados inconstitucionais pelo Poder Judiciário", tornando erga omnes a decisão proferida pelo STF (MARTINS; MENDES, 2001, p. 24);

3) A alteração mais significativa foi a representação interventiva, confiada ao Procurador-Geral da República e versava sobre conflitos federativos. Aparecem aqui os primeiros sinais do controle concentrado. No entanto, a competência do Procurador-Geral da República restringia-se aos atos estaduais em desobediência aos princípios federativos (MARTINS; MENDES, 2001, p. 25);

4) A referida Constituição também trazia em seu artigo 68 um recado explícito do constituinte ao Judiciário: "é vedado ao Poder Judiciário conhecer das questões exclusivamente políticas" (MARTINS; MENDES, 2001, p. 25). O que demonstra que apesar da concessão feita ao Procurador-Geral da República, o constituinte mantinha uma postura rígida da doutrina de separação dos poderes, não parecia adepto a delegações de poderes ao Judiciário. 
Se nos fosse permitido uma leitura dos acontecimentos em torno do controle de constitucionalidade e de sua implantação em 1891 até a Constituição de 1934, que poderíamos afirmar? A tendência desenhada na Constituição de 1891 de formalização da participação do Judiciário na solução dos conflitos públicos, ou seja, a possibilidade de o Judiciário opinar sobre questões do interesse geral, ganhou muita força com a possibilidade de o Procurador-Geral da República interpor uma representação interventiva no tocante aos conflitos federativos. Esse ponto também se constitui na primeira experiência constitucional brasileira de algo próximo de um controle concentrado.

Contudo, a faculdade do Procurador-Geral da República em propor uma representação interventiva veio acompanhada de uma restrição à declaração de inconstitucionalidade por parte dos tribunais, que passam a necessitar de maioria para tal feito. De certa forma, essa postura do constituinte pode ser interpretada, para além de uma melhor operacionalidade processual que preserve a segurança jurídica, como uma imposição de limites, que se coaduna perfeitamente com a vedação literal de qualquer intromissão do Poder Judiciário nas questões de cunho político.

Parece claro a tendência de enquadramento do Judiciário na doutrina clássica da separação dos poderes. Ou seja, ele não deve estar tão próximo a ponto de participar das questões de cunho político e não deve estar tão longe a ponto de não se imiscuir na estrutura formal das decisões políticas.

\section{O Estado Novo e a Carta outorgada de 1937}

A história das constituições brasileiras é, em boa parte, a história das rupturas políticas. Desde 1891, a cada ruptura nasce uma nova Constituição. A Carta constitucional outorgada em 1937 não fugiu à regra. De forte inspiração fascista, a Carta de 37 não trouxe, como de hábito, alguns dos 
princípios fundamentais estabelecidos nas constituições anteriores como, por exemplo, a separação entre os poderes.

A Carta de 37 caracterizava-se por uma forte centralização do poder nas mãos do Presidente da República; transferia para o Executivo, por exemplo, o controle total sobre a economia nacional. A Carta também lançava mão de algumas promessas como reformar o processo representativo (legislativo e executivo) entre outras coisas. Entretanto, não parece ser muito útil discutir o conteúdo da Carta de 1937, por um simples motivo:

A Carta de 1937 não teve, porém, aplicação regular. Muitos de seus dispositivos permaneceram letra morta. Houve ditadura pura e simples, com todo o Poder Executivo e Legislativo concentrado nas mãos do Presidente da República, que legislava por via de decretos-leis que ele próprio depois aplicava, como órgão do Executivo (SILVA, 2002, p. 83).

O contexto geral aplica-se perfeitamente às alterações ocorridas no controle de constitucionalidade. Nesse ponto, a Carta Constitucional de 1937 constituiu um inequívoco retrocesso. Embora não tenha alterado a forma de controle difuso expressa na Constituição anterior, ela previa em seu art. 96 a faculdade do Presidente da República de remeter de novo ao Congresso lei que fosse declarada inconstitucional e que, na visão presidencial, atentasse contra o bem-estar do povo e a promoção ou defesa do interesse nacional. Caso as Casas Parlamentares concordassem, observado o quorum de 2/3 cada uma, a decisão do STF perdia sua validade (MARTINS; MENDES, 2001, p. 26-28). Em suma, o intervalo que vai da Carta de 1937 até a Constituição de 1946 não pode ser interpretado como parte de um processo de institucionalização dos mecanismos de controle democrático, seja pela via do Parlamento, seja pela via do Judiciário.

Parece claro que a organização judiciária e a forma de controle constitucional na Carta de 37 não têm nenhuma importância do ponto de vista da discussão que fazemos aqui sobre equilíbrio de poderes, conflitos federativos, garantias 
individuais etc. O texto de 37 definiu o único poder soberano possível, o único árbitro da federação e a única fonte da qual poderiam emergir quaisquer direitos sociais e individuais: a Presidência da República (ARANTES, 1994, p. 69).

\section{A redemocratização e a Constituição de 1946}

A Constituição brasileira de 1946 sofreu forte influência do movimento constitucional que tomou conta da Europa no final da Segunda Guerra Mundial. A participação do Brasil na guerra contra as forças nazifascistas serviu de base para os apelos de redemocratização da sociedade brasileira. As Constituições aprovadas na Europa (Itália, França, Alemanha, lugoslávia, Polônia, entre outras) influenciaram a reconstitucionalização do Brasil (SILVA, 2002, p. 83-84).

No que concerne à estrutura do Supremo Tribunal Federal, nada foi mudado. O desenho institucional continuou o mesmo - em caso de vacância, os ministros eram escolhidos pelo Presidente e sabatinados pelo Senado Federal. Ocorreram alterações nas competências do STF, "as competências originárias e privativas, as de grau de recurso ordinário, e as de grau de recurso extraordinário" (ARANTES, 1994, p. 73). Essas alterações na competência, que buscavam tornar mais racional e lógico o sistema, eram basicamente de cunho administrativo e processual.

No desenho do controle de constitucionalidade, que nos interessa mais especificamente, a Constituição de 1946 preservou alguns aspectos da Constituição de 1934 como: a exigência de maioria absoluta dos membros do Tribunal para a eficácia da decisão declaratória de inconstitucionalidade e manteve a atribuição do Senado para suspender a execução da lei declarada inconstitucional pelo Supremo Tribunal Federal.

Apesar de o controle de constitucionalidade ter preservado o modelo difuso-incidental, a Constituição Federal de 1946 reforçou a repre- 
sentação interventiva efetuada pelo Procurador-Geral da República estabelecendo explicitamente os princípios em que o Procurador podia basear sua representação de inconstitucionalidade. São eles (MARTINS; MENDES, 2001, p. 33):
a) a forma republicana;
b) independência e harmonia entre os poderes;
c) temporalidade das funções eletivas, limitada a duração destas a das funções federais correspondentes;
d) proibição da reeleição de governadores e prefeitos para o período imediato;
e) autonomia municipal;
f) prestação de contas da administração;
g) garantias do Poder Judiciário.

A Constituição de 1946 parece trazer consigo os primeiros passos de uma mudança que vai tornar-se mais nítida na Constituição de 1988. O constituinte brasileiro de 1946 dá o primeiro sinal de que lhe interessa judicializar aspectos que antes estavam restritos ao mundo político. Com isso, a doutrina da separação dos poderes vai sendo flexibilizada.

É interessante destacar que as Constituições de 1946 e 1988 não foram elaboradas com base em um projeto preordenado que fosse oferecido previamente à Assembléia Constituinte. Talvez, não por acaso, sejam elas pioneiras na delegação de poderes de controle ao Judiciário. A abertura política antecedida de um regime de exceção criou o ambiente propício às mudanças institucionais que mitigassem o forte poder exercido pelo Executivo. Essa tendência de expansão do poder judicial em momentos de forte mudança do status político, econômico e/ou social culmina com a experiência européia ${ }^{7}$.

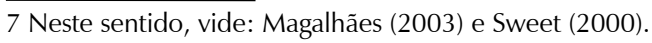


No entanto, a forma de expressar essa judicialização mostrou-se muito contida. Como sabemos, a titularidade da representação de inconstitucionalidade ficou restrita ao Procurador-Geral da República, o que, em outras palavras, significa que o poder de judicializar estava nas mãos do Presidente da República, tendo em vista a grande afinidade do Procurador-Geral da República com a presidência ${ }^{8}$. Ou seja, podemos notar, na dinâmica do controle de constitucionalidade, o fortalecimento da experiência de uma forma de controle (o concentrado) e, paralelamente, a existência, nessa nova forma de controle, de um processo de judicialização tutelado pelo poder Executivo.

Outro ponto importante foi que os efeitos da judicialização estavam reservados às esferas estadual e municipal, em última análise isso significa que a judicialização dos conflitos entre os entes federados (Estados e Municípios) passa a ser feita pelo Procurador-Geral da República sob coordenação efetiva do Presidente da República. O que corrobora com a tendência centralizadora da política no Brasil e torna o controle de constitucionalidade um instrumento desta centralização (ARANTES, 1994). Em uma frase, é possível dizer que temos os primeiros fortes sinais de uma judicialização tutelada (ou controlada, ou ainda centralizada) dos conflitos políticos federativos.

Do ponto de vista da evolução da revisão abstrata no Brasil, a Constituição de 1934 - que deu os primeiros passos - e a de 1946, demonstraram que as alterações que permitiram uma participação do Poder Judiciário como mediador privilegiado do embate político só foi possível mediante um rigoroso controle sobre o que poderia ser judicializado. A estreita ligação entre o Procurador-Geral e o Presidente da República, apesar de informal, corrobora esse controle. A ideia parece que foi bem

8 Por algum tempo o debate sobre a exclusividade de Procurador-Geral da República logo se mostrou controvertido, devido principalmente à legitimidade do pré-julgamento que este fazia das questões conflitivas antes de apresentá-las em forma de representação interventiva. Esse problema tornou-se mais evidente após a Emenda no 16, de 26/11/1965. Trataremos dele mais adiante. 
incorporada pelo sistema político, tanto que, findo o período democrático (1946-1964) e instalado o regime de exceção, esta forma de controle sobre o que poderia ser judicializado foi aperfeiçoada, tendo no Procurador-Geral da República sua pedra de toque.

\section{O Regime militar de 1964 e a Constituição de 1967}

O golpe militar de 1964 é mais um capítulo da tumultuada vida política e constitucional brasileira. Como ocorreu com o golpe de 1937, as instituições democráticas foram bastante prejudicadas e perderam seu valor constitucional, como fica claro no preâmbulo do Ato Institucional no 1: "Assim, a revolução vitoriosa, como o Poder Constituinte, se legitima por si mesma. Ela destitui o governo anterior e tem a capacidade de constituir o novo governo. Nela se contem a força normativa, inerente ao Poder Constituinte. Ela edita normas jurídicas, sem que nisto seja limitada pela normatividade anterior à sua vitória" (ARANTES, 1994, p. 77).

Apesar de seu tom forte, o regime militar procurou, minimamente, conviver com as instituições democráticas, embora utilizasse, sempre que Ihe conviesse, a sua legitimidade em si mesmo.

Ressalta-se, entretanto, que o Regime militar pós-64 diferencia-se da Ditadura Vargas não só por ter permitido o funcionamento de algumas instituições representativas e a manifestação do judiciário em vários momentos, como também porque suas inovações foram mantidas em grande parte pela Constituição de 88, particularmente no campo do controle de constitucionalidade das leis (ARANTES, 1994, p. 86)

É interessante notar que o regime militar teve a oportunidade de extinguir o controle difuso de constitucionalidade quando este estava em debate na reforma do judiciário. "O próprio Supremo Tribunal Federal propôs a introdução da representação de inconstitucionalidade como for- 
ma de ação direta, como controle abstrato das normas. E foi além quando sugeriu, ele mesmo, 'uma prejudicial de inconstitucionalidade, a ser suscitada, exclusivamente, pelo próprio Supremo Tribunal Federal ou pelo Procurador-Geral da República, em qualquer processo em curso perante outro juízo`, ou seja, uma espécie de avacatória para assuntos constitucionais relevantes" (ARANTES, 1994, p. 79).

Como sabemos, a proposta do STF não vingou e foi garantido ao Procurador-Geral da República encaminhar apenas o que, em seu entendimento, constituísse lesão à Constituição. Isso explica o fato de não ter sido aceita também a prejudicial de inconstitucionalidade proposta pelo Supremo na reforma. Existe um entendimento de que o então Ministro da Justiça, Juracy Magalhães, quando negou a proposta do Supremo, o tenha feito pensando na manutenção do controle de constitucionalidade difuso (ARANTES, 1994, p. 79). Em nosso entendimento, a resolução desse problema foi bem prática. Se a proposta do Supremo Tribunal Federal tivesse sido aceita, o Executivo perderia o controle sobre o que poderia ser analisado de forma abstrata, ou seja, sobre o que poderia ser judicializado. Ao invés de ter apenas o Procurador-Geral da República como intérprete dos problemas constitucionais, também teríamos todos os ministros do Supremo. Controlar um Procurador, que é indicado a cada dois anos pelo Presidente da República, é bem diferente do que controlar mais de dez juízes com todas as suas prerrogativas e garantias, entre elas a vitaliciedade.

No que se refere ao controle de constitucionalidade, o Ato Institucional no 2, 27/10/1965, aumentou de onze para dezesseis o número de juízes do Supremo Tribunal Federal e suspendeu as garantias de vitaliciedade e inamovabilidade de toda a magistratura. Em seguida, a Emenda no 16, de 26 de novembro de 1965, instituiu, ao lado da representação interventiva, e nos mesmos moldes, o controle abstrato de normas estaduais e federais, ampliando a capacidade do Procurador-Geral da República de judicializar conflitos políticos. 
Apesar da dependência política do Presidente da República e do regime de exceção que vigorava no Brasil, o Procurador-Geral da República foi, sem sombra de dúvida, a grande figura das alterações constitucionais ocorridas no Regime, foi o maior protagonista da engenharia institucional patrocinada pelos militares no controle de constitucionalidade. Tornou-se o garante, ou o único intérprete, da constitucionalidade abstrata das leis.

Para além do controle abstrato de normas estaduais e federais, que por si só já se configura na possibilidade de alargar a intervenção do Judiciário no mundo político, o Procurador-Geral da República teve a ampliação de sua representação para fins de intervenção "não só a observância dos chamados princípios sensíveis (art. 10, VII), mas também prover a execução da lei federal (art. 10, VI, 1a parte) e por fim, a Emenda no 7 , de 1977, introduziu, ao lado da representação para fins de interpretação da lei ou ato normativo federal ou estadual, outorgando ao ProcuradorGeral da República a legitimidade para provocar o pronunciamento do Supremo Tribunal Federal (art. 119, I, e). E, segundo a exposição de motivos apresentada ao Congresso Nacional, esse instituto deveria evitar a proliferação de demandas, com a fixação imediata da correta exegese da lei" (MARTINS; MENDES, 2001, p. 44).

As novas atribuições e prerrogativas do Procurador-Geral da República transferiram-Ihe para o centro das disputas políticas. Não demorou muito para que surgissem novas controvérsias em torno de seu papel à frente do controle abstrato, como bem relata abaixo o Ex-ProcuradorGeral da República, Alcino Salazar:

quando o Procurador entendesse que a arguição era improcedente não a encaminharia; e ela só poderia entrar no Tribunal por mãos do Procurador. Então, ele se tornaria um julgador ou, pior do que isso, trancaria o processo. A Procuradoria-Geral da República seria uma antecâmara de onde não poderiam passar representações (grifo nosso). Cairíamos, evidentemente, no arbítrio injustificado, praticamente supressivo da competência deste alto Tribunal, sempre que 
o Procurador-Geral entendesse improcedente e infundada a arguição (SALAZAR apud DANTAS, 1996, p. 89).

Em suma, autoridades políticas desprovidas de legitimidade legal para propor ação declaratória de inconstitucionalidade queriam que o Procurador-Geral da República se tornasse porta voz de seus interesses. Como a engenharia institucional montada pelos militares não contemplava essa cortesia, não tardou para que isso gerasse muita celeuma política e vastas discussões jurídicas 9 .

A arquitetura institucional imposta pelos militares consagra e amplia $^{10}$ a experiência anterior de controle sobre o que poderia ser judicializado. Ou seja, na perspectiva do controle de constitucionalidade, ocorre um forte processo de centralização, caracterizado pelo monopólio da propositura por parte do Procurador-Geral da República. O forte vínculo político que esta alta autoridade possuía com o Presidente caracteriza uma patente tutela do uso deste mecanismo. A discussão sobre o monopólio da ação direta de inconstitucionalidade pelo Procurador-Geral da República não acaba por aqui, os constituintes de 1988 deram a resposta.

\section{Democracia de novo e a Constituição de 1988}

A abertura política negociada entre os militares e a elite política civil em 1985 culminou com a proclamação de uma nova Constituição em 1988. Existe uma vasta bibliografia recente que trata do tema do fim da ditadura militar e a redemocratização do país, concentrando o debate nos problemas de consolidação da democracia ${ }^{11}$. A Constituição de 1988

9 Gilmar Mendes discorre sobre os pontos de vista jurídicos da época (2001, p. 45-66).

10 Uma prova irrefutável dessa ampliação foi o estabelecimento do controle abstrato das normas estaduais e federais.

11 Para uma breve introdução dessa problemática ver: O`Donnell (1994, 1998 e 1999) e Zaverucha (2000). 
também tem sido alvo frequente de publicações, principalmente sobre temas relacionados ao controle de constitucionalidade e aos direitos fundamentais. Apesar de a profusão de trabalhos que abordam essas temáticas ser realmente instigante, vamos manter a linha adotada desde o início, dando realce às mudanças no desenho institucional e na forma de se exercer o controle de constitucionalidade.

Apesar de evitarmos uma inserção mais abrangente sobre o processo de construção da Constituição de 1988, é sempre bem-vindo um panorama geral sobre o que foi esse processo de construção. Nesse sentido, é bem esclarecedora a análise abaixo:

Resultante de impasses de todo o tipo, negociações intrincadas, filtragens sucessivas e coalizões precárias no decorrer de dezenove meses, o projeto aprovado pela Assembléia Constituinte peca por sua falta de unidade lógico-formal, pela ausência de fios condutores entre suas normas, incisos e parágrafos, pela carência de um espírito balizador entre seus capítulos, pela a inexistência de identidade e ideologias próprias, pela profusão de casuísmos, arcaísmos e corporativismos ao lado de medidas inovadoras, modernas e democráticas, pela confusão entre temas materialmente constitucionais e temas formalmente constitucionais e pela conjugação desarticulada entre propostas de caráter estrutural e medidas de natureza meramente conjuntural (FARIA, 1989, p. 18-19).

De fato, são inegáveis os vícios e privilégios, como também são inegáveis as inovações e os avanços que ela consagrou. Talvez a maior prova dessa ambiguidade sejam as cinquenta e duas emendas à Constituição feitas após sua promulgação. Boa parte delas procura desfazer ou refazer o que os constituintes de 1988 estabeleceram ${ }^{12}$.

12 No que tange as reformas constitucionais no Brasil ver: Machado (2001); Melo (2002) e Abrucio \& Loureiro (2002). 
No que se refere ao Poder Judiciário, as alterações seguiram a tônica do todo, segundo Manoel Gonçalves Ferreira Filho: "A reestruturação do Poder Judiciário não era prioridade de qualquer das correntes que predominavam na Constituinte de 87-88. Por isso, o tema não suscitou maiores controvérsias. Mas, apesar dessa apatia, uma reestruturação de monta houve, decorrente de uma combinação de propostas desconexas e de variada inspiração" (FERREIRA FILHO, 1995, p. 29) ${ }^{13}$.

No que se refere à reestruturação do Poder Judiciário na Constituição de 1988, boa parte da literatura circunscreve o tema dentro da arena de democratização. Ou seja, as alterações estabelecidas eram apenas mais um ingrediente, dentre tantos, necessários à consolidação da recémnascida democracia brasileira ${ }^{14}$.

Para o constitucionalista paulista, a Constituição de 1988 trouxe uma nova filosofia para a função de julgar. No seu entender, o enfoque dado pela atual Constituição vai de encontro à "forma tradicional" e amplia consideravelmente a capacidade de participação do juiz.

Quanto à função de julgar trouxe a Constituição nova um outro enfoque, bem distinto do tradicional (...) Com efeito, o texto importou o due process of law substantivo do direito anglo-americano (art. 5', LIV), afora o aspecto formal, de há muito presente no nosso sistema por meio dos princípios de ampla defesa, do contraditório etc., mantido no art. $5^{\circ}$, LV da Constituição. Assim pode hoje o magistrado inquietar-se sobre a razoabilidade da lei, a proporcionalidade dos encargos que acarreta etc. Quando antes não Ihe cabia senão ser a voz da lei (FERREIRA FILHO, 1995, p. 30)

13 Entre as mudanças o autor cita as que o lobby dos magistrados conseguiu, para além de suas benesses corporativas: a autonomia financeira do Judiciário e dar aos tribunais o provimento dos cargos de juiz, livrando estes de dever favores ao Executivo.

14 Nesse sentido ver: Reis (1986) e Lamounier (1987). 
Esse ponto está sensivelmente expresso nas palavras de um dos mais experientes juízes do Supremo Tribunal Federal, o ex-ministro Moreira Alves, quando aborda essa temática no direito processual:

Os incisos LIV e LV versam sobre o devido processo legal, o direito à ampla defesa e o princípio do contraditório. Com isso não há questão processual nenhuma que não chegue ao STF sob a alegação de ofensa a um desses dois incisos, nem haverá lei alguma que não permita a possibilidade de se invocar uma má interpretação que, no fundo, acarretaria a aplicação de uma lei propriamente inexistente, tendo em vista que aquela interpretação não se coadunaria com o conteúdo significativo da norma (MOREIRA ALVES, 1997, p. 273).

Ferreira Filho ainda aponta três alterações importantes do ponto de vista da engenharia constitucional de 1988:

1) No que tange à administração pública, o autor alerta, mais de uma vez, sobre a quebra da doutrina clássica. A Carta Constitucional de 1988, paradoxalmente, permite dissolver a doutrina da Separação dos Poderes contida nela mesma. Na Carta, "o Judiciário controla a administração pública não só em vista dos interesses individuais, mas também em prol do interesse geral" (FERREIRA FILHO, 1995, p. 34);

2) "A Constituição consagra o alargamento de campo da ação popular. Nela, essa ação visa a proteger não apenas o patrimônio público, mas igualmente a moralidade administrativa, o meio ambiente, o patrimônio histórico e cultural" (FERREIRA FILHO, 1995, p. 34);

3) "O Ministério Público passa a ter legitimidade para promover o inquérito civil e a ação civil pública, para a proteção do patrimônio público e social, do meio ambiente e de outros interesses difusos e coletivos (...) A primeira dessas consequências é que o Estado passa a manter um serviço público não apenas voltado para fiscalizar o respeito à lei mas para controlar a atuação da administração pública no campo das opções discricionárias (...) Por fim, o texto consagra a noção de interesses difusos. Ora, é ela suficientemente 
ampla e flexível para permitir a intervenção do Ministério Público em variadíssimos campos, como o do interesse do consumidor" (FERREIRA FILHO, 1995, p. 35).

Ferreira Filho defende a tese de que as alterações ocorridas em 1988 transformaram o Poder Judiciário em um poder de caráter político. "Tire-se desta análise o primeiro registro de algo que repetirá, o papel do Judiciário torna-se acentuadamente de caráter político. No caso do controle de constitucionalidade, a ação direta de inconstitucionalidade, que se generaliza, e a ação direta de constitucionalidade, fazem dele um legislador negativo, enquanto a ação de inconstitucionalidade por omissão e o mandado de injunção o impelem a tornar-se legislador ativo" (FERREIRA FILHO, 1995, p. 33).

É interessante notar que, o que Ferreira Filho denomina de quebra do modelo tradicional de atuação do Judiciário é interpretado por outros autores como uma mudança do paradigma constitucional, que acompanha a passagem do Estado liberal para o Estado de bem-estar social. Em outras palavras, "as constituições contemporâneas não se limitam às regras clássicas do constitucionalismo dos séculos XVIII e XIX. Trazem uma vasta estrutura de normas diretivas e programáticas e criam alterações extremamente importantes no quadro tradicional do controle de constitucionalidade" (VIEIRA, 2002, p. 34).

De uma forma geral, não há como negar a participação cada vez mais ativa do Judiciário na política. Boa parte dos argumentos apontados por Ferreira Filho são fortes indicadores desse processo de judicialização. Se considerarmos o controle de constitucionalidade como o ponto chave desse processo, a principal alteração nesse sentido foi, sem dúvida, a ampliação da capacidade de propositura da ação direta de inconstitucionalidade, ou mais especificamente, o art. 103 da Constituição Federal ${ }^{15}$.

15 Segundo o artigo 103 da CF podem propor ação direta de inconstitucionalidade: o Presidente da República, o Procurador-Geral da República, as mesas do Senado Federal, da Câmara dos Deputados, das Assembléias Legislativas dos Estados e do Distrito Federal, o Governador de Estado, o Conselho Federal da OAB, Partidos Políticos com representação no Congresso Nacional e Confederações ou Entidade de Classe de âmbito nacional. 
Como é sabido de todos, o Congresso Nacional rejeitou o modelo adotado na maioria dos países que possuem o controle abstrato. Nesse modelo, a legitimidade para propor a ação de inconstitucionalidade está restrita a $1 / 3$ do parlamento. Portanto, o controle de agenda sobre o que pode ser judicializado é bem mais rigoroso que o nosso.

Tudo indica que as discussões doutrinárias em torno do monopólio da propositura da ação direta de inconstitucionalidade por parte do Procurador-Geral da República durante o regime militar tenham potencializado o vigor do constituinte em ampliar o rol de entes capacitados. A insatisfação de várias lideranças políticas em não ter suas queixas encaminhadas ao Supremo Tribunal Federal pelo Procurador-Geral da República pode ter ocasionado essa reação. A abertura foi de tal forma que suscitou comentários dos próprios Ministros do Supremo:

Eu não conheço - talvez seja ignorância minha - nenhum país de controle concentrado que tenha uma lista de legitimados ativos, como aquele que se encontra no art. 103 da CF (MOREIRA ALVES, 1997, p. 276) ${ }^{16}$.

Os legitimados ativos do art. 103 da CF foram, sem dúvida, responsáveis pelo esvaziamento do controle difuso. A preferência pelo modelo concentrado faz-se presente sob dois pontos de vista:

1) Ponto de vista político: a ausência de custo político para quem propõe, a possibilidade de veto de uma proposta do Executivo ou da maioria legislativa, o caráter de maior visibilidade de uma ação direta de inconstitucionalidade e seu efeito midiático provocado pela abrangência erga omnes do julgamento;

2) Ponto de vista jurídico: a ampla legitimação, a presteza e a celeridade desse modelo processual, dotado inclusive da possibilidade de se sus-

16 Ao final do texto anexamos um apêndice que confirma, de forma comparada, o número expressivo de legitimados ativos capazes de iniciar um processo de revisão abstrata da legislação no Brasil. 
pender imediatamente a eficácia do ato normativo questionado, mediante pedido de cautelar.

Seja justificado pela via política ou jurídica, o que fica claro é que

a Constituição de 1988 reduziu o significado do controle de constitucionalidade incidental ou difuso, ao ampliar, de forma marcante, a legitimação para propositura da ação direta de inconstitucionalidade (art. 103, CF), permitindo que, praticamente, todas as controvérsias constitucionais relevantes sejam submetidas ao Supremo Tribunal Federal mediante processo de controle abstrato de normas. (MARTINS; MENDES, 2001, p. 63).

Em outras palavras, ao ampliar, de forma significativa o círculo de legitimados ativos aptos a provocar o Supremo Tribunal Federal no processo de controle abstrato das normas, acabou o constituinte por restringir, de maneira radical, a amplitude do controle difuso de constitucionalidade.

Essa não foi a única consequência da abertura aos legitimados ativos do art. 103 da CF. Nas discussões sobre a legitimidade efetiva para propor ação direta de inconstitucionalidade gerou-se uma disputa, dentro do Supremo Tribunal Federal, sobre a necessidade ou não de restringir ao máximo essa legitimidade. A jurisprudência tem dado vitória aos ministros que são a favor da restrição. Foi criada, em alguns casos, como, por exemplo, dos Governadores e Assembléias Legislativas, a relação de pertinência.

Eu que fiz parte da corrente do STF, que afinal foi vencedora, de restringir ao máximo o conceito de entidade de classe, certa vez, caricaturalmente, salientei: se formos admitir um conceito amplíssimo de entidade de classe, daqui a pouco vão fundar a Associação Nacional dos Defensores da Constituição, de tal sorte que teremos todas as ações do Brasil que não agradarem a essa associação devidamente ajuizadas no STF. Naquele momento, obviamente, achou-se que era caricatura, mas não demorou muito quando apareceu uma Associação dos Defensores da Cidadania, o que, em última análise, é quase a mesma coisa (MOREIRA ALVES, 1997, p. 276). 
É possível perceber um tratamento diferenciado entre os diversos entes legitimados, por exemplo, a Ordem dos Advogados do Brasil (OAB) foi agraciada pelo Supremo Tribunal Federal, o Conselho da OAB não precisa demonstrar pertinência temática em nenhuma de suas ações. Dificilmente encontraremos algo parecido em outro país ${ }^{17}$.

Os Partidos Políticos também possuem legitimidade irrestrita, indo de encontro à tendência internacional em qualificar as minorias. Na Europa, berço do controle concentrado, a legitimidade de propositura é facultada a um percentual de parlamentares, que geralmente fica em torno de 1/3 da Casa. No Brasil, o constituinte rompe de vez com a centralização da propositura, via monopólio da ação direta de inconstitucionalidade por parte do Procurador-Geral da República, instituindo um rol eclético de legitimados ativos.

Dentre esses, o que mais vem causando celeuma nos debates e na doutrina é o direito de propositura das confederações sindicais e das entidades de classe de âmbito nacional. A diversidade e falta de regulamentação obrigou os ministros a disciplinar minimamente o tema.

Se considerarmos que somente as confederações sindicais e entidades de classe propuseram, até 11 de junho de 1999, 555 ações diretas de inconstitucionalidade e que os julgamentos dessas ações resultaram no reconhecimento de legitimidade de 92 confederações sindicais ou entidades de classe, as mais das vezes após intensa discussão sob a sua caracterização como entidade de classe, teremos de constatar que, em vez de contribuir para a maior efetividade do controle abstrato, o exercício do direito de propositura da ação direta por esses entes tem servido para tumultuar ainda mais a já problemática situação do Supremo Tribunal Federal no que concerne à sobrecarga de trabalhos estatístiCOS (MARTINS; MENDES, 2001, p. 108)

Para Mendes e Martins a outorga do direito de propositura a um único órgão acaba por restringir a possibilidade de impugnação de atos

18 Ver o apêndice no final do capítulo. 
normativos. No entanto, a ampliação desmesurada desse direito acaba por provocar um excesso de trabalho sem maior proveito para a ordem e segurança jurídicas. Para esses autores, a exclusão das associações e confederações sindicais não alteraria o grau de vigilância exercido pelos demais entes legitimados.

É de Kelsen a afirmação de que, embora a ação popular pudesse oferecer, talvez, a mais forte garantia para o bom desempenho da Corte enquanto guardiã da Constituição, não parecia recomendável a adoção dessa fórmula, sob pena de colocar em risco o funcionamento razoável do órgão pela sobrecarga de trabalho e pela ameaça do perigo da litigância aventureira ou de má fé (MARTINS; MENDES, 2001, p. 111).

\section{Desenho constitucional da revisão judicial: tutela, autonomia e judicialização}

No que concerne ao desenho institucional, é possível dizer que o Supremo Tribunal Federal sofreu poucas alterações. Quanto à forma de ingresso, por exemplo, desde seu surgimento com a Proclamação da República até os dias atuais cabe, exclusivamente, ao Presidente da República a escolha dos Ministros daquela casa. O que se alterou foi número de vagas, uma vez que, dada a instabilidade institucional e política marcante em nossa história, a redução e o aumento do número de Ministros serviu aos interesses dos dirigentes políticos em cada época. Além das alterações no número de vagas para o STF, foi possível observar a aposentadoria compulsória de juízes que se posicionassem contra a política do Presidente (tanto na era Vargas como no Regime Militar).

As alterações na arquitetura institucional do Supremo tinham por finalidade, na maioria das vezes, legitimar as forças políticas emergentes. Quase sempre essa liturgia de legitimação era acompanhada de ações 
unilaterais do Executivo, caracterizadas por um total desrespeito às regras do jogo existente. Como já afirmamos, a ditadura Vargas (1937-1945) e o Regime Militar (1964-1985) expressam bem esses traços.

Entretanto, o ponto que mais alterações sofreu foi, sem dúvida, o das competências. Nos períodos de exceção, geralmente ocorriam restrições estabelecidas por legislações autoritárias. Um bom exemplo foi a lei de Segurança Nacional. Nos períodos de abertura política o que se via era justamente o contrário, na Constituição de 1988 as competências do Supremo Tribunal Federal obedeceram a uma lógica de expansão, pouco vista em outros países. Como vimos, quase tudo pode ser motivo de uma ação, seja ela inicial ou recursal, no Supremo Tribunal Federal.

A trajetória da Revisão judicial no Brasil também foi alvo de significativas alterações. Da importação do modelo norte-americano de controle de constitucionalidade pela Constituição de 1891 até o atual formato do controle de constitucionalidade na Constituição de 1988, muita coisa foi modificada. De forma semelhante à arquitetura institucional do STF, as alterações ocorridas no controle de constitucionalidade brasileiro foram articuladas, principalmente, pelo Executivo.

Vejamos como esse influenciou as mudanças ocorridas:

1) Na Constituição de 1891, podemos afirmar que o modelo difuso implantado (cópia do que funcionava nos Estados Unidos), em sua vertente pura, impede qualquer tipo de controle por parte do Executivo, apesar da ausência de interferência por parte do Executivo, esse modelo foi implantado no Brasil, provavelmente porque a importância do Judiciário no cenário político da época era pequena;

2) Na Constituição de 1934, a liberdade dada ao Judiciário pela Constituição de 1891 é revista, cristaliza-se a noção de não interferência do Judiciário em assuntos políticos ao prescrever que a declaração de inconstitucionalidade somente poderia ser realizada pela maioria da to- 
talidade de membros dos tribunais, restringindo, assim, seu campo de atuação. Nessa mesma direção, a referida Constituição também trazia em seu artigo 68 um recado explícito do constituinte ao Judiciário: "é vedado ao Poder Judiciário conhecer das questões exclusivamente políticas". Ao passo que restringia a atuação do Judiciário em sua arena difusa, o constituinte ampliava a participação dessa instituição por uma via mais centralizada e estratégica. Estamos falando da alteração mais significativa, que foi a representação interventiva, confiada ao Procurador-Geral da República que versava sobre conflitos federativos. Portanto, fica claro o desenho de um vigoroso controle, para qual foram criados constrangimentos, seja limitando as decisões por maioria, seja proibindo o conhecimento de conflitos políticos, ou ainda, reservando ao Procurado-Geral da República, homem de confiança do Presidente, a representação interventiva;

3) A Constituição de 1946, como já foi dito, preservou alguns aspectos da Constituição de 1934 como: a) a exigência de maioria absoluta dos membros do Tribunal para a eficácia da decisão declaratória de inconstitucionalidade e b) manteve a atribuição do Senado para suspender a execução da lei declarada inconstitucional pelo Supremo Tribunal Federal. A Constituição Federal de 1946 também alterou a representação interventiva efetuada pelo Procurador-Geral da República estabelecendo explicitamente os princípios em que o Procurador podia basear sua representação de inconstitucionalidade. Isso pode ser interpretado como uma restrição, visto que no formato anterior não havia nenhuma indicação formal. Tudo isso indica que não houve, no que tange ao controle de constitucionalidade, alterações significativas. Em se tratando do formato do controle de constitucionalidade pouca coisa foi mudada, os controles e constrangimentos estabelecidos em 1934 ganham apenas 
uma normatização mais precisa no que diz respeito aos objetos da representação interventiva;

4) Na Constituição de 1967 ocorreu um expressivo aumento da jurisdição passível de ser acionada por ação direta de inconstitucionalidade pelo Procurador-Geral da República. Como vimos, além do controle abstrato de normas estaduais e federais, o Procurador-Geral da República teve a ampliação de sua representação para fins de intervenção. Essa nova posição aumentou em muito o atrito do Procurador-Geral da República com as mais diversas autoridades políticas. Como vimos, essa situação provocou uma ampla discussão sobre a delicada posição do Procurador-Geral da República frente aos interesses do Governo. Talvez boa parte destes debates tenha influenciado um posicionamento radical do constituinte em 1988. Tanto o número de legitimados ativos, como as prerrogativas de independência do Ministério Público foram revistas;

5) A Constituição de 1988 quebra de vez com qualquer perspectiva de controle ou constrangimento por parte do Executivo. O rol de legitimados do artigo 103 da Constituição Federal: Presidente da República, as mesas do Senado Federal, da Câmara dos Deputados, das Assembléias Legislativas dos Estados e do Distrito Federal, os Governadores de Estado, o Conselho Federal da OAB, os Partidos Políticos com representação no Congresso Nacional e as Confederações ou Entidades de Classe de âmbito nacional, juntamente com a infinita capacidade que a Constituição de 1988 oferece de ser questionada em juízo, estes, são ingredientes resistíveis a qualquer forma de centralização do processo político;

Argumentamos que para compreender melhor o desenho do controle concentrado e suas consequências para o fenômeno da judicialização na política brasileira é preciso observar o surgimento de algumas variáveis explicativas: 
a) Autonomia do Poder Judiciário: essa variável é fundamental, sem ela seria muito difícil a constituição de um cenário propício à judicialização da política. Como vimos, ela foi sendo conquistada durante a história republicana brasileira e tem na Constituição de 1988 o seu melhor momento;

b) Quantidade de Legitimados Ativos: o aumento do número de legitimados ativos na Constituição de 1988 quebrou com o monopólio de propositura da ação de revisão abstrata do Procurador-Geral da República, em outras palavras, o aumento dos legitimados, que em termos comparativos é considerável, culminou em um aumento também expressivo de ações de revisão judicial;

\section{Conclusão}

Desde o início, e sempre sob a ótica do controle de constitucionalidade, o processo de fortalecimento do Judiciário frente aos demais ramos de poder foi lento e estrategicamente autorizado pelo Executivo. Este Poder, em suas diversas faces históricas, foi o verdadeiro arquiteto da política judiciária. Por meio de decretos, criou e regulou por muito tempo o mais alto tribunal da República. Na história política brasileira, repleta de passagens autoritárias, a dependência política dos tribunais aos demais ramos de poder, particularmente ao Executivo, só perde força na Constituição de 1988. Apesar de ter sido uma constante na história constitucional, a busca por uma maior autonomia e independência do Judiciário só tomou fortes contornos em 1988. A autonomia conquistada será um importante vetor explicativo do processo de judicialização da política.

No que diz respeito à evolução da revisão abstrata de constitucionalidade, foi possível observar uma tendência de controle, por parte do Executivo, do que poderia ser judicializado. Entre os artifícios de controle utilizado os mais contundentes foram a vedação explícita de julgamento 
de "questões políticas" e a indicação do Procurador por parte do Presidente da República (ocorrida a cada dois anos), tornando o Procurador uma figura chave para o entendimento da política de judicialização dos conflitos políticos/constitucionais.

A tendência que se traçou, desde o surgimento dos primeiros sinais de um possível controle de constitucionalidade concentrado em 1934 até a Constituição de 1988, foi de um forte processo de centralização do que poderia ser judicializado (observado nas Constituições de 1934, 1946 e 1967) e findou com a fraqueza deste poder de centralização (Constituição de 1988).

A grande resultante destas mudanças políticas e institucionais é um Judiciário autônomo com capacidade de interferir em decisões de relevo no cenário nacional. Cabem aos cientistas sociais compreenderem quais os significados destas mudanças, que não estão restritas apenas à revisão judicial.

\section{The trajectory of Judicial Review in the Brazilian Constitutional Design: tutelage, autonomy and judicialization}

\section{Abstract}

The judicial institutions remained for a long time in the shadow of the political phenomena and theory in Latin America. This article presents some thoughts on one of these institutions, the judicial review. The main idea is to demonstrate the trajectory of this legal instrument that has become a key piece to understand the judicialization of politics in Brazil. In this sense, the paper tries to identify the factors that lead to the judicialization of politics, considering as background the evolution of the judicial institutions in Brazil during the republican period, and in particular the institutions responsible for the judicial review.

Keywords: Judicial review. Autonomy. Judicialization. 


\section{Referências}

ABRÚCIO, Fernando Luiz; LOUREIRO, Maria Rita . O Estado numa era de reformas: os anos FHC. Brasília: MP, SEGES, p. 2002, p. 75-119.

ARANTES, Rogério Bastos. O controle de constitucionalidade das leis no Brasil: a construção de um sistema híbrido. Dissertação de Mestrado, Departamento de Ciência Política da USP, São Paulo, 1994.

CARVALHO, José Murilo de. A construção da ordem / Teatro das sombras. Rio de Janeiro: Relume Dumara, 1998.

DANTAS, Ivo. O valor da Constituição. Rio de Janeiro: Renovar, 1996.

FARIA, José Eduardo. O Brasil pós-Constituinte. Rio de Janeiro: Graal, 1989.

FERREIRA FILHO, Manoel Gonçalves. O Poder Judiciário na Constituição de 1988: judicialização da política e politização da justiça. Revista da Procuradoria Geral do Município de São Paulo, São Paulo, 1995.

KOERNER, Andrei. Judiciário e Cidadania na Constituição da República Brasileira. São Paulo: DCP-USP / Hucitec, 1998.

LAMOUNIER, Bolívar. Perspectivas da consolidação democrática: o caso brasileiro. Revista Brasileira de Ciências Sociais, n. 4, v. 2, São Paulo, 1987.

MACHADO, Regina Helena. Reforma do Estado ou Reforma da Constituição? Rio de Janeiro: Lumen Júris, 2001.

MAGALHÃES, Pedro Coutinho. The limits to Judicialization: legislative politics and constitutional review in the Iberian democracies. Phd Dissertation, Ohio State University, 2003.

MARTINS, Ives Gandra da Silva; MENDES, Gilmar Ferreira. Controle concentrado de Constitucionalidade. São Paulo: Saraiva, 2001.

MELO, Marcus André. Reformas Constitucionais no Brasil: instituições políticas e processo decisório. Rio de Janeiro: Revan, Brasília, Ministério da Cultura, 2002. MOREIRA ALVES, José Carlos. Força Vinculante das Decisões do Supremo. Declaração de Constitucionalidade. Juizados Especiais. Valorização dos Recursos Processuais. Revista dos Tribunais, Cadernos de Direito Constitucional e Ciência Política, Ano 5 , n. 18, São Paulo, 1997.

O'DONNELL, Guillermo. Democracia Delegativa. São Paulo, Revista Novos Estudos CEBRAP, 1994.

. Horizontal Accountability in New Democracies. Journal of Democracy, v. 9, n. 3, Washington, 1998. 
Janeiro, 1999.

Teoria Democrática e Política Comparada. In: Dados, v. 42, n. 4, Rio de REIS, Fábio Wanderley. Constituição Pacto e Poder. Revista Brasileira de Ciências Sociais, n. 1, v. 1, São Paulo, 1986.

SCHWARTZ, Stuart B. Burocracia e Sociedade no Brasil Colonial. São Paulo: Ed. Perspectiva, 1979.

SILVA, José Afonso da. Curso de Direito Constitucional Positivo. São Paulo: Ed. Malheiros, 2002.

SWEET, A. Stone. Governing with Judgers: Constitutional Politics in Europe. Oxford: Oxford University Press, 2000.

VIEIRA, Oscar Vilhena. Supremo Tribunal Federal: jurisprudência política. São Paulo: Editora Malheiros, 2002.

ZAVERUCHA, Jorge. Frágil Democracia: Collor, Itamar, FHC e os Militares. Rio de Janeiro: Civilização Brasileira, 2000.

Recebido: 19/12/2006

Aceite final: 24/01/2007 


\section{Apêndice}

Revisão Abstrata da Legislação nas Democracia Européias ${ }^{18}$

\begin{tabular}{|c|c|}
\hline Países & Podem propor Revisão da Legislação a posteriori contra a legislação Central ou Federal \\
\hline Áustria & Governadores de Estado, 1/3 da Câmara baixa e 1/3 da Câmara alta. \\
\hline Bélgica & Governo, Governadores das regiões e comunidades, 2/3 dos membros das assembléias regionais. \\
\hline Bulgária & $\begin{array}{l}\text { Presidente da República, 20\% dos membros do parlamento, Governo, Suprema Corte de Cassação, } \\
\text { Suprema Corte Administrativa e Chefe dos Procuradores. }\end{array}$ \\
\hline Croácia & $\begin{array}{l}\text { Presidente, } 1 / 5 \text { dos membros do parlamento, os comitês do parlamento, Ombudsman, Suprema } \\
\text { Corte. }\end{array}$ \\
\hline $\begin{array}{l}\text { República } \\
\text { Checa }\end{array}$ & $\begin{array}{l}\text { Presidente, aproximadamente } 20 \% \text { dos membros do parlamento (41), aproximadamente } 21 \% \text { dos } \\
\text { senadores (17), o Governo e um escolhido da Suprema Corte. }\end{array}$ \\
\hline Estônia & Chanceler legal. \\
\hline França & - \\
\hline Alemanha & Governo federal, Governadores de estado e $1 / 3$ dos membros da câmara baixa. \\
\hline Hungria & Todas as pessoas. \\
\hline Itália & Governadores regionais. \\
\hline Polônia & $\begin{array}{l}\text { Presidente, Presidente da Câmara baixa, Presidente da Câmara alta, Primeiro Ministro, aproxima- } \\
\text { damente } 11 \% \text { dos membros do parlamento ( } 50), 30 \% \text { dos senadores (30), Presidente da Suprema } \\
\text { Corte, Presidente da chefia administrativa da Corte, Procurador Geral, Ombudsman, Presidente da } \\
\text { Suprema Câmara de Controle, unidades locais de alto governo, Conselho Nacional do Judiciário, } \\
\text { Sindicatos, Associações de trabalhadores e Igrejas. }\end{array}$ \\
\hline Portugal & $\begin{array}{l}\text { Presidente, Presidente do Parlamento, Primeiro Ministro, } 10 \% \text { dos membros do parlamento, } \\
\text { Ombudsman, Procurador -Geral, Ministros da República, Assembléias legislativas regionais (ALR), } \\
\text { Presidente da ALR e } 10 \% \text { dos membros da ALR. }\end{array}$ \\
\hline Romênia & - \\
\hline Eslováquia & Presidente, Governo, 20\% dos membros do Parlamento e Procurador- Geral. \\
\hline Eslovênia & $\begin{array}{l}\text { Câmara baixa, } 1 / 3 \text { dos membros do parlamento, Conselho Nacional, Governo, Procurador do } \\
\text { Estado, Banco da Eslovênia, Auditor Geral, Ombudsman, corpos representantes das comunidades } \\
\text { locais, Sindicatos, qualquer pessoa jurídica. }\end{array}$ \\
\hline Espanha & $\begin{array}{l}\text { Primeiro Ministro, aproximadamente } 14 \% \text { dos membros do parlamento (50), aproximadamente } \\
19 \% \text { dos senadores ( } 50) \text {, Ombudsman, Governadores das comunidades autônomas e assembleias } \\
\text { das comunidades autônomas. }\end{array}$ \\
\hline Latia & $\begin{array}{l}\text { Presidente, } 1 / 3 \text { dos Membros do } \\
\text { Parlamento, Governo e o Pleno da Corte. }\end{array}$ \\
\hline Lituânia & Presidente, Governo e 20\% dos Membros do Parlamento. \\
\hline
\end{tabular}

Este Apêndice foi adaptado de Magalhães (2003, apud textos constitucionais da International Constitutional law website, p. 140-141).

18 Todos os países incluídos são democracias eleitorais livres e membros do conselho europeu. 